\title{
DIVERSITY OF MICROCHIROPTERAN BATS IN FOREST FRAGMENTS AND RIPARIAN ZONES IN AN OIL PALM PLANTATION ESTATE
}

\author{
Fauziah Syamsi \\ The Program of Educational Biology of Riau Kepulauan University, Batam
}

Oil palm is one of the world's most rapidly increasing crops, and covers over 13 million ha in Southeast Asia. Sumatra has a relatively long history of commercial oil palm cultivation, and many plantations have replaced rain forest. Typically these monoculture plantations support much fewer species than do forest, however there is very little information available for bats. We sampled insectivorous bats in West Sumatra in a mature oil palm plantation where some forest cover was retained in forest fragments on hills and along rivers. Using a total of 180 harp trap nights we compared the bat community in three habitat types: forest patches, riparian zone and plantation area. In total we captured 1108 bats representing 21 species and 5 families, and the majority of these (in terms of species and abundance) were found in forest fragments. Oil palm plantation was found to be a poor habitat for bats - only four individuals of two species were captured. Riparian areas supported intermediate diversity, and might be important as wildlife corridors between forest fragments.

\section{Key: Diversity, Microchiropteran Bats}

\section{INTRODUCTION}

Bats constitute the second most species-rich order of mammals (Wilson and Reeder, 2005) and up to half of mammal species in tropical forests (Findley, 1993). They are divided into two sub orders, the Megachiropteran and Microchiropteran. Megachiropteran (Old World Fruit bat) has important roles, they serve as pollinators, seed dispersers, and Microchiropteran bats serve as predator of insects as well as small vertebrates (Findley, 1993; Altringham, 1996). Microchiropteran bat has large number of species than Megachiropteran. Microchiropteran has 834 species and Megachiropteran has 167 species (Hutson et al., 2001).

In recent decades, bat populations have experienced global declines, a trend linked to extensive, recent habitat loss (Mickleburgh et al., 2002). In Southeast Asia, 20\% of bat species are predicted to become extinct by 2100 (Lane et al., 2006). Nonetheless, bats are frequently overlooked in biodiversity assessments and fragmentation research, possibly because they are widely perceived to be at low risk of extinction due to their ability to fly (Struebig et al., 2008).

PT. Kencana Sawit Indonesia (KSI) has three habitat type, they are forest patches, riparian zone and plantation area. Hall et al. (2004) suggested most of bats occupy various types of habitat. The high diversity of habitat and various ecological structures resulted in high diversity of bats especially on primary forest or closed habitat while in the open habitat which are described as secondary habitat, the bats diversity tend to be low.

In the establishment of the oil palm itself, large area of forest, which form the habitat for the bats, are destroyed and thus removing their food source and roosting site that bats depend on and this may have serious consequences on bats diversity (Timoh, 2006). Little information about Microchiropteran bats in fragmented habitat and plantation area. Study about that will be gave much information to conserve bat and hope can reduce the rate of extinction. The aims of this study are to explore the species richness, diversity, abundance of Microchiropteran bats in forest patches, riparian and plantation area 


\section{METHODS}

\section{a. Study area}

The study was conducted at Oil Palm Plantation Estate PT. KSI (ZSL Indonesia Research Station), Solok Selatan, West Sumatra, Indonesia. Captured bats in three different habitat types.

Forest patches around oil palm estate of PT KSI is a fragmented forest with an area of \pm 300 ha. Struebig, et al. (2008) classify an area of 200-500 ha has a medium forest fragments. Some fragments show the abundance and species richness of bats is higher compared to continuous forest. Nevertheless, the decline may continue to occur in the future because of the effects of fragmentation in a long time. Riparian zone stretches along both sides of the river contained in the PT. KSI. This area has various topographies. Harp traps placed at locations that ramps topography with a clear trail forest. For plantation area, harp trap was setting in mature oil palm tree based on not too close to the riparian and forest patches.

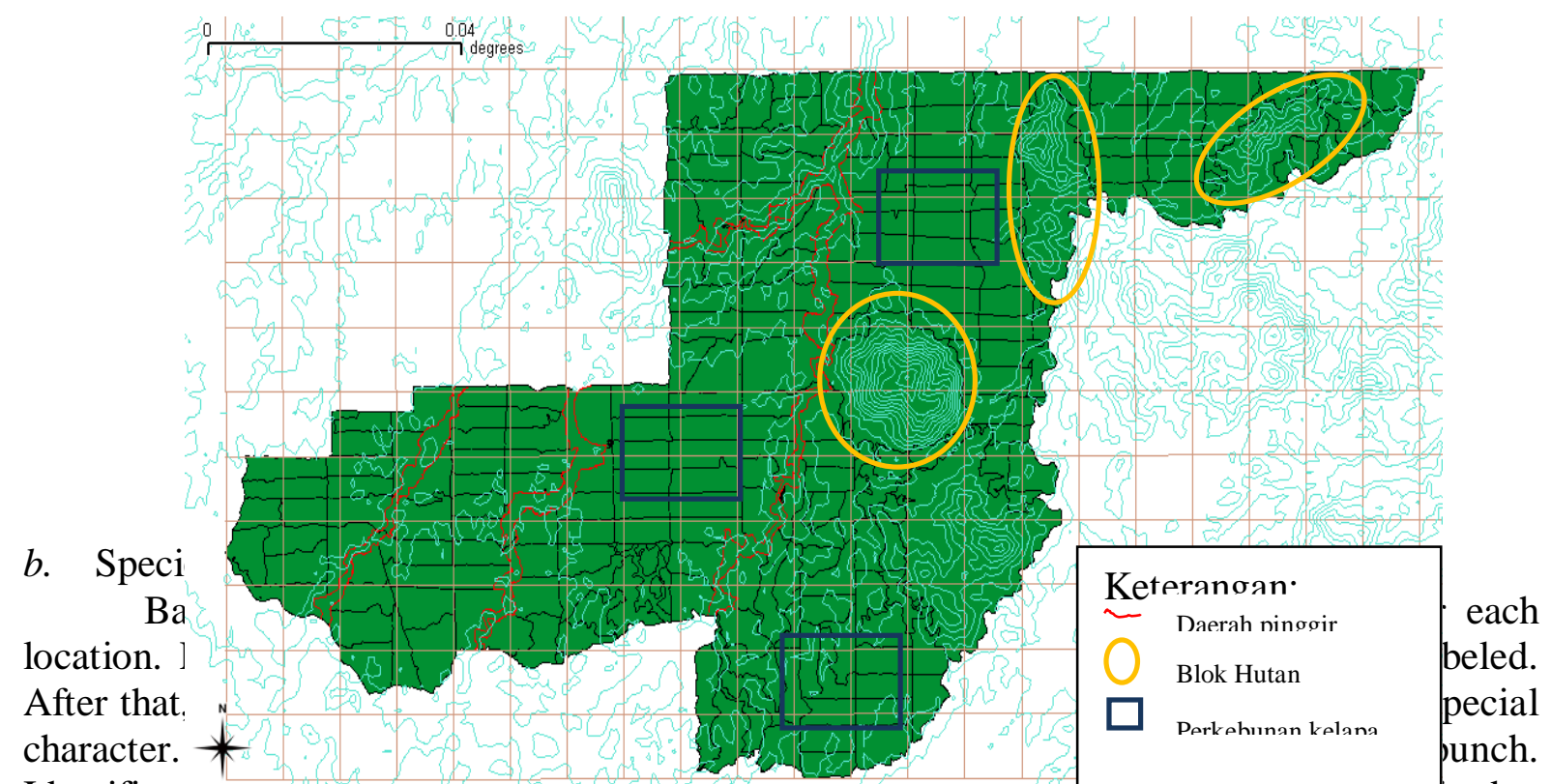

Identification species tollowing Payne et al. (2UUO); Kingston et al. (ZUOJ) dan struedig dan Sujarno (2006).

\section{c. Data Analysis}

This research analyzed on species richness with species accumulation graph following Ludwig and Reynolds, 1988 cit. Estrada and Estrada 2001. Bat diversity estimate analyzed with Shannon Wiener index (H') following Stilling, 2002; Struebig dan Sujarno, 2005. Species abundance shown with rank abundance graph Whittaker plots following Stoner, 2005.

\section{RESULT}

a. Bats captured in three habitat types in an oil palm plantation estate

Table1. Number of captures Microchiropteran species in three habitat types in PT KSI 


\begin{tabular}{|c|c|c|c|c|c|c|c|}
\hline \multirow{2}{*}{ Family/Taxon } & \multirow{2}{*}{$\begin{array}{l}\text { Species } \\
\text { code }\end{array}$} & \multirow{2}{*}{$\begin{array}{l}\text { Redlist } \\
\text { Status }^{\mathrm{a}}\end{array}$} & \multirow{2}{*}{ Category ${ }^{\mathrm{b}}$} & \multicolumn{3}{|c|}{ Number captures ${ }^{\mathrm{c}}$} & \multirow{2}{*}{$\Sigma$} \\
\hline & & & & $\mathrm{F}$ & $\mathrm{R}$ & $\mathrm{P}$ & \\
\hline \multicolumn{8}{|l|}{ Hipposideridae } \\
\hline Hipposideros bicolor & Hibi & LC & $\mathrm{E}$ & 134 & 10 & 2 & 146 \\
\hline Hipposidderos cervinus & Hice & LC & $\mathrm{E}$ & 755 & 65 & & 820 \\
\hline Hipposideros cf. diadema & Hidi $c f$ & LC & A & & 1 & & 1 \\
\hline Hipposideros cineraceus & Hici & LC & A & 1 & & & 1 \\
\hline Hipposideros diadema & Hidi & LC & A & & & 1 & 1 \\
\hline Hipposideros galeritus & Higa & LC & $\mathrm{D}$ & 16 & 4 & & 20 \\
\hline Hipposideros larvatus & Hila & LC & B & 4 & & & 4 \\
\hline \multicolumn{8}{|l|}{ Megadermatidae } \\
\hline Megaderma spasma & Mesp & LC & A & 1 & & & 1 \\
\hline \multicolumn{8}{|l|}{ Nycteridae } \\
\hline Nycteris tragata & Nytr & NT & A & 1 & & & 1 \\
\hline \multicolumn{8}{|l|}{ Rhinolophidae } \\
\hline Rhinolophus acuminatus & Rhac & LC & $\mathrm{D}$ & 7 & 7 & & 14 \\
\hline Rhinolopuhus affinis & Rhaf & LC & B & & 4 & & 4 \\
\hline Rhinolophus borneensis & Rhbo & LC & B & 2 & & & 2 \\
\hline Rhinolophus lepidus & Rhle & LC & $\mathrm{E}$ & 57 & 3 & & 60 \\
\hline Rhinolophus luctus & Rhlu & LC & B & 2 & 3 & & 5 \\
\hline Rhinolophus pusillus & Rhpu & LC & D & 11 & & & 11 \\
\hline Rhinolophus sedulus & Rhse & NT & A & 1 & & & 1 \\
\hline Rhinolophus stheno & Rhst & LC & B & 3 & 1 & & 4 \\
\hline $\begin{array}{l}\text { Rhinolophus trifoliatus } \\
\text { Vespertilionidae } \\
\text { (Kerivoulinae) }\end{array}$ & Rhtr & LC & $\mathrm{C}$ & 6 & 2 & & 8 \\
\hline $\begin{array}{l}\text { Kerivoula papillosa } \\
\text { Vespertilionidae } \\
\text { (Vespertilioninae) }\end{array}$ & Kepa & LC & A & 1 & & & 1 \\
\hline $\begin{array}{l}\text { Myotis muricola } \\
\text { Vespertilionidae } \\
\text { (Murininae) }\end{array}$ & Mymu & LC & A & & & 1 & 1 \\
\hline Murina suilla & Musu & LC & B & 2 & & & 2 \\
\hline TOTAL & & & & 1004 & 100 & 4 & 1108 \\
\hline
\end{tabular}

${ }^{a}$ IUCN red list status following review by IUCN 2010 (accessed on Januari 2011): LC, Least Concern; NT, Near Threatened

${ }^{\mathrm{b}}$ Spesies categori based on number individual were captured: A, rare species (1); B, relative rare species (2-5); C, relative common species (6-10); D, Common species (1150 ); E, most common species (>50).

${ }^{\mathrm{c}}$ Number capture each habitat types : F, Forest patches; R, Riparian; P, Plantation.

b. Bat species richness in three habitat type in an oil palm plantation estate

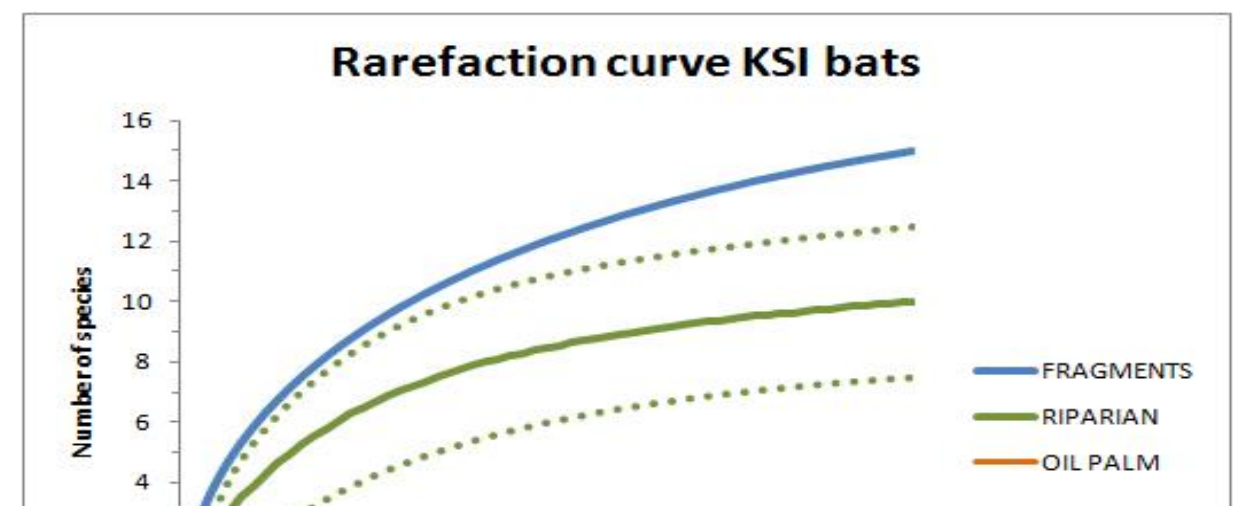


Figure 1. Rarefaction curves for insectivorous bats captured in three habitat types.

c. Bats diversity in three habitat types in Palm oil plantation estate

Table2. Diversity index of insectivorous bats in each habitat types

\begin{tabular}{ll}
\hline Habitat type & Diversity index \\
\hline Forest patches & 0,94 \\
Riparian & 1,36 \\
Plantation & 1,04 \\
\hline
\end{tabular}

d. Bats abundance in three habitat types in Oil palm plantation estate

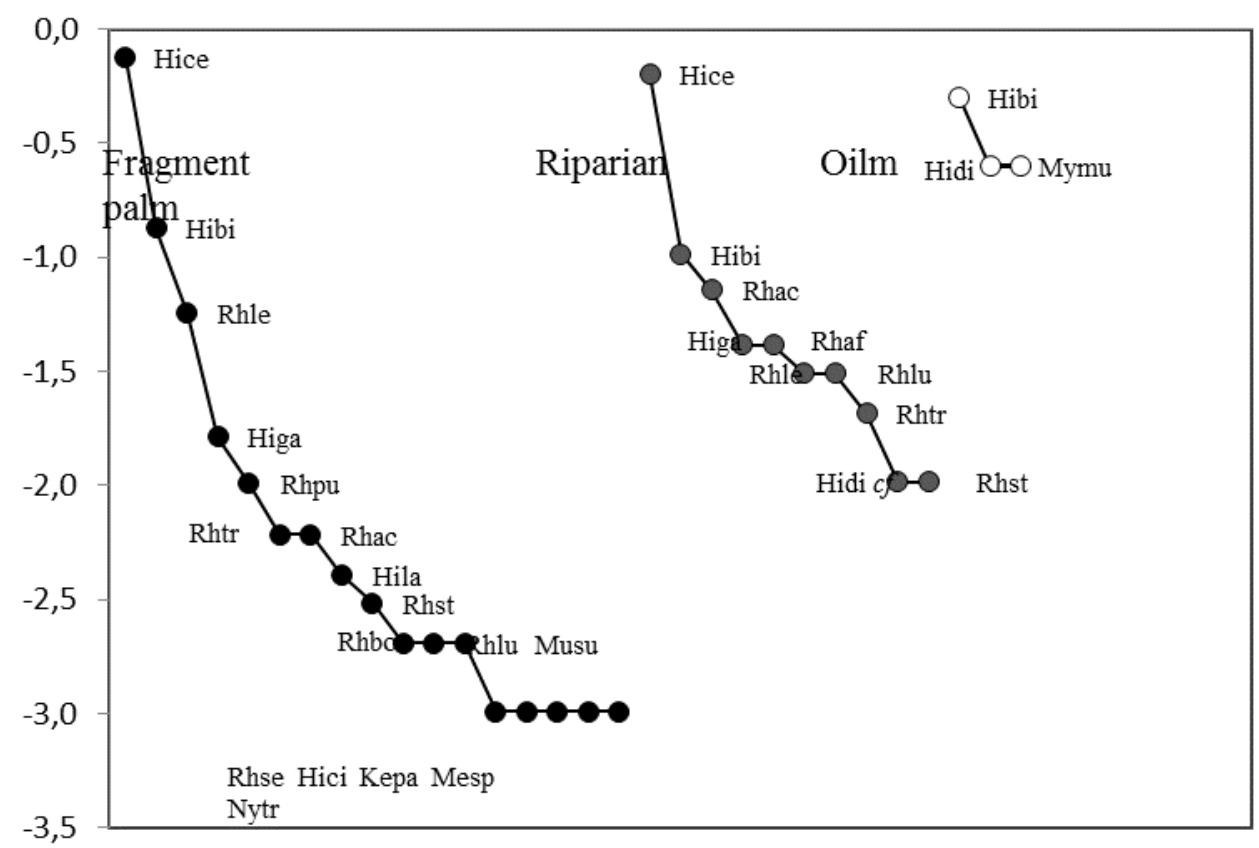

Figure2. Rank abundance (Whittaker) plots for insectivorous bats in three habitat types in the Oil palm plantation estate. Species are ranked according to the abundance of each species (n) and the total abundance of all species for each habitat types $(\mathrm{N})$.

\section{CONCLUSION}

Our surveys indicate, as forest patches is a good habitat for insectivorous bats. That there is a highly species richness and abundance, but less diversity index because ratio number of individual one species and number of individual of all species (Pi) has less than do riparian and plantation. Besides that, forest patches also supported many rare species. Riparian zone is an important habitat for insectivorous bats because of highly diversity index and intermediate species richness and abundance. Plantation area is not good habitat for insectivorous bats because of intermediate diversity index and less species richness and abundance. Design an oil palm plantation estate with provide forest fragment and forest riparian is good solution for decrease rate of animal extinction, especially for bats. 


\section{LITERATURE CITED}

Altringham, J.D. 1996. Bats: Biology and Behaviour. Oxford University Press. Oxford.

Estrada, A. dan R.C. Estrada. 2001. Bat species richness in live fences and in corridors of residual rain forest vegetation at Los Tuxtlas, Mexico. Ecography 24: 94-102.

Findley, J.S. 1993. Bats: a community perspective. Cambridge University Press. Cambridge.

Hall, L.S., Grigg, G.G, Moritz, C., Ketol, B., Sait, I., Marni, W. and M.T. Abdullah. 2004. Biogeography of fruit bats in Southeast Asia. Sarawak Museum Journal.

Hutson, A.M., S.P. Mickleburgh dan P.A. Racey. 2001. Microchiropteran Bats: Global Status Survey and Conservation Action Plan. IUCN/SSC Chiroptera Specialist Group. IUCN, Gland, Switzerland and Cambridge, UK. x+258 pp

Kingston, T., Lim, B.L., Akbar, Z. 2005. Bats of Krau Wildlife Reserve. University Kebangsaan Malaysia, Bangi.

Lane, D.J.W., Kingston, T., Lee, B.P.Y-H., 2006. Dramatic decline in bat species richness in Singapore, with implications for Southeast Asia. Biological Conservation 131, 584593.

Mickleburgh, S.P., Hutson, A.M., Racey, P.A., 2002. A review of the global conservation status of bats. Oryx 36, 18-34.

Payne, J. C.M. Francis, K. Phillips, S.N. Kartikasari. 2000. Panduan Lapangan Mamalia Di Kalimantan, Sabah, Sarawak, dan Brunei Darussalam. Prima center. Jakarta.

Stilling, P. 2002. Ecology: Theories and Applications. Fourth edition. Prentice-Hall, INC. New Jersey.

Stoner, K.E. 2005. Phyllostomid Bat Community Structure and Abundance in Two Contrasting Tropical Dry Forests. Biotropica. 37(4): 591-599

Struebig, M dan R. Sujarno. 2006. Survey Kelelawar Menggunakan Perangkap Harpa: Petunjuk Latihan dan Kunci Identifikasi untuk Kelelawar di Kalimantan. The Kalimantan Bat Project.1-35.

Struebig, M.J; Kingston, T; Zubaid, A; Adnan, A.M; Rositter, S.J. 2008. Conservation Value of Forest Fragments to Paleotropical Bats. Biological Conservation 141 (2008) 21122126.

Timoh, J.R. 2006. Diversity and relative abundance of Bats in an oil palm plantation and neighboring forest in Bratak Oil Palm Estate, Bau, Sarawak. Animal Resource Science and Management Program. Faculty of resource science and technology Universiti malaysia sarawak

Wilson, D.E. and D.M. Reeder. 1993. Mammal Species of the World: a Taxonomic and Geographic Reference. $2^{\text {nd }}$ edition. Smithsonian Institution Press. Washington D.C. 